\title{
DEVELOPMENT AND CHARACTERIZATION OF A TAMBAQUI SAUSAGE
}

\author{
Elaboração e caracterização de embutido de tambaqui
}

\author{
Fernando Sleder ${ }^{1}$, Daiane Alves Cardoso ${ }^{2}$, Luciana Kimie Savay-da-Silva ${ }^{3}$, Janessa Sampaio de Abreu ${ }^{4}$, \\ Anderson Castro Soares de Oliveira ${ }^{5}$, Edivaldo Sampaio de Almeida Filho ${ }^{6}$
}

\begin{abstract}
In Brazil, fish are sold in retail fresh or frozen, whole, or gutted. To increase consumption, convenient products with good sensory attributes should be offered. The objective of this study was to develop and characterize, through physicochemical, microbiologica, and sensory traits, a fresh sausage of tambaqui fish (Colossoma macropomum). Three formulations, with different percentages of fat $(0,4.5$, and $9 \%)$ were developed. To determine shelf life, samples of the products were refrigerated at $4{ }^{\circ} \mathrm{C}$ for 12 days and microbiological analyses were performed on days $0,3,7$, and 12 . Analyses of centesimal composition, shear force, cooking weight loss, and water-holding capacity were carried out. The shelf life of the fresh sausages was estimated at 7 days of storage. The sensory attributes evaluated were aroma, color, flavor, succulence, texture, and overall appearance. All treatments showed high acceptance rates, above $80 \%$. The treatment with $9 \%$ fat showed the highest mean values in the evaluated attributes, with $86.6 \%$, $83.4 \%, 92 \%, 88.2 \%, 87.2 \%$, and $85.8 \%$ for aroma, color, flavor, succulence, texture and overall appearance, respectively. The centesimal composition of the treatments showed the following variations in $\mathrm{g} .100 \mathrm{~g}^{-1}$ : moisture, 72.73 to 68.82 ; protein, 18.85 to 18.90; lipids, 2.90 to 8.33; and ash, 3.86 to 4.20. Shear force varied from 5.92 to $8.14 \mathrm{~N}$; water-holding capacity varied from 71.83 to $74.71 \%$ and cooking weight loss, from 24.21 to $26.59 \%$.
\end{abstract}

Index terms: Fish; fresh sausage; shelf life; sensory.

\section{RESUMO}

No Brasil, a comercialização de peixes é realizada com o produto fresco ou congelado. Para se conseguir o aumento de consumo, se faz necessário oferecer produtos de conveniência e com valor agregado. Produtos processados possuem atributos sensoriais diferenciados além de facilidade no preparo. O objetivo deste trabalho foi elaborar e caracterizar, através de análises físico-químicas, microbiológicas e sensoriais, um embutido a base de tambaqui (Colossoma macropomum). Foram desenvolvidas três formulações, que distinguiam entre si com relação ao percentual de gordura: $0 \%, 4,5 \%$ e $9 \%$. Para determinação da vida de prateleira, amostras dos produtos foram armazenadas sob refrigeração $4{ }^{\circ} \mathrm{C}$ por 12 dias e realizaram-se análises microbiológicas nos dias $0,3,7$ e 12. Foram realizadas análises de composição centesimal, força de cisalhamento, perda de peso por cocção e capacidade de retenção de água. Os atributos sensoriais avaliados foram aroma, cor, sabor, suculência, textura e aparência global. Todos os tratamentos apresentaram altos índices de aceitação, acima de $80 \%$, porém, o tratamento com $9 \%$ de gordura apresentou as maiores medias nos atributos avaliados, $86,6 \%, 83,4 \%, 92 \%, 88,2 \%, 87,2 \%$, e $85,8 \%$ respectivamente para aroma, cor, sabor, suculência, textura e aparência global. A composição centesimal dos tratamentos apresentou as seguintes variações em g.100 $\mathrm{g}^{-1}$ : umidade 72,73 a 68,82 ; proteína 18,85 a 18,90; lipídeos 2,90 a 8,33 e cinza 3,86 a 4,20. A força de cisalhamento oscilou de 5,92 a 8,14 N; a capacidade de retenção de água variou de 71,83 a $74,71 \%$ e a perda de peso por cocção de 24,21 a $26,59 \%$.

Termos para indexação: Pescado; linguiça; vida de prateleira; sensorial.

\section{INTRODUCTION}

The consumption of fish and derived products has significantly increased in the last few years, as these foods have been increasingly recognized as important sources of nutrients for human health (Gonçalves, 2011). According to Burger (2008), the nutritional value of fish and the dissemination of research associating it with health improvements have increased the interest in this food. In his study conducted aiming to obtain data on consumption and awareness about fish, the author found that over $90 \%$ of the interviewees had heard about its benefits.

Fish is still sold in its entirety (whole body) cooled or frozen, with no previous processes included to add value to the product. In addition to the use of refrigeration, other forms of processing can be used on fish. Processed

\footnotetext{
1Universidade Federal de Mato Grosso/UFMT - Av. Fernando Corrêa da Costa - 2367 - Boa Esperança - Cuiabá - MT - Brasil - sleder12@gmail.com ${ }^{2}$ Universidade Federal de Mato Grosso/UFMT - Cuiabá - MT - Brasil

${ }^{3}$ Universidade Federal de Mato Grosso/UFMT - Departamento de Alimentos e Nutrição - Cuiabá - MT - Brasil

${ }^{4}$ Universidade Federal de Mato Grosso/UFMT - Departamento de Zootecnia e Extensão Rural - Cuiabá - MT - Brasil

${ }^{5}$ Universidade Federal de Mato Grosso/UFMT - Departamento de Estatística, Instituto de Ciências Exatas e da Terra - Cuiabá - MT - Brasil

Universidade Federal de Mato Grosso/UFMT - Departamento de Produção Animal - Cuiabá - MT - Brasil

Received in april 30, 2015 and approved in august 24, 2015
}

Ciênc. Agrotec., Lavras, v. 39, n. 6, p. 604-612, nov./dez., 2015 
products have differentiated sensory traits such as flavor, texture, and ease of preparation (Lara; Garbelini; Delbem, 2007).

Although fish has adequate nutritional properties and its consumption is associated with a healthy lifestyle, some restrictions to its consumption exist, justified by the following aspects: versatility, situational relevance, negative properties (bones and odor), economic factors, and convenience (Leek; Maddock; Foxall, 2000). The authors suggest that marketing actions and further research for the development of new products are necessary.

Food products that spare time and that are prepared with practicality are present in supermarkets and homes because of the contemporary lifestyle. People need products of easy and fast preparation and sometimes in smaller portions (Brunner; Horst; Siegrist, 2010). Scholderer and Trondsen (2008) report that fish in its fresh form, recently captured, cooled or frozen in its entirety, is cited as an inconvenient food. However, fishbased products are not considered to be so, as they feature practicality and convenience. Those authors indicated an inverse relationship between the consumption of fish products and the consumption of fresh fish. These negative evaluations are responsible for the substitution of the way traditional fish is supplied to the consumer for processed products.

Given the foregoing, and considering the need for the development of new fish-derived products, the objective of this study was to develop and characterize a fresh sausage of tambaqui (Colossoma macropomum) through physicochemical, microbiological and sensory analyses.

\section{MATERIAL AND METHODS}

The raw material utilized in this study was 64 fish of the tambaqui species (Colossoma macropomum), originating from the Fish Farming Section of the Experimental Farm (15 51'06.0"S; 56 04'13.9'W) at Federal University of Mato Grosso (UFMT), in Mato Grosso State, center of Brazil. After the capture, the fish were slaughtered by immersion in ice slurry (ice:fish ratio of $1: 1$, for $5 \mathrm{~min}$ ). After slaughter, they were washed with chlorinated water ( $5 \mathrm{ppm})$ and eviscerated, and their meat portion was removed.

To measure the freshness of the raw material, analyses of potential hydrogen $(\mathrm{pH})$, in ph meter (Tekna T-1000, Brazil) (Pregnolatto; Pregnolatto, 1985), and total volatile base nitrogen (TVBN) were performed (Brasil, 1981).

\section{Development of the sausage}

To develop the sausage, the meat portion was ground in an 8-mm-diameter grinder (Poli equipment, PCP22L model, Brazil) generating a homogeneous dough. After grinding, the other ingredients were mixed with the dough and subsequently homogenized until they were completely incorporated. The ingredients are listed in Table 1. Three sausageformulations were developed, changing only their fat concentration. In the control (C) formulation, no fat (pig lard) was added. In the other formulations, fat was added at the concentrations of $4.5 \%$ (F1) and 9\% (F2). The following ingredients were utilized: common salt, onion, garlic, parsley, basil, black pepper, oregano, monosodium glutamate, citric acid, curing salts, emulsifier, and stabilizer.

Table 1: Ingredients (\%) used in the development of the fresh sausage.

\begin{tabular}{lccc}
\hline \multirow{2}{*}{ Ingredient } & \multicolumn{3}{c}{ Formulation (\%) } \\
\cline { 2 - 4 } \multicolumn{1}{c}{ Tambaqui meat } & C & F1 & F2 \\
Fat & 0 & 91 & 86.5 \\
Salt & 1.7 & 1.7 & 9 \\
Dry onion & 0.2 & 0.2 & 0.2 \\
Dry garlic & 0.2 & 0.2 & 0.2 \\
Dry parsley & 0.1 & 0.1 & 0.1 \\
Basil & 0.1 & 0.1 & 0.1 \\
Black pepper & 0.1 & 0.1 & 0.1 \\
Oregano & 0.05 & 0.05 & 0.05 \\
Sugar & 0.05 & 0.05 & 0.05 \\
Monosodium glutamate & 0.1 & 0.1 & 0.1 \\
Antioxidant (citric acid) & 0.3 & 0.3 & 0.3 \\
Carrageenan & 0.25 & 0.25 & 0.25 \\
Curing salt & 0.15 & 0.15 & 0.15 \\
Sodium tripolyphosphate & 1.2 & 1.2 & 1.2 \\
\hline
\end{tabular}

Natural pig gut with $36 \mathrm{~mm}$ caliber was used as casing. The sausage was conditioned in lowdensity polyethylene according to each treatment and stored in a refrigerator $\left(4{ }^{\circ} \mathrm{C} \pm 0.5^{\circ} \mathrm{C}\right.$ - Incoterm Thermometer L-178/05 model, Brazil) until the moment of the physicochemical, microbiological, and sensory analyses. 


\section{Physicochemical analyses}

The centesimal composition of the following components was determined in samples of the meat portion of the tambaqui and in the developed sausages: moisture, crude protein, ash, and total lipids, according to Brasil (2011). The carbohydrate content was obtained by calculating the difference, and the caloric value was determined by multiplying the lipid content by 9 and the protein and carbohydrate content by 4 (Brasil, 2003).

A texturometer (Stable Micro System, TA.XT/Plus model, England) was used for the instrumental assessment of texture. The sausages were baked at a temperature of $170{ }^{\circ} \mathrm{C}$ until the internal temperature reached $70{ }^{\circ} \mathrm{C}$ in an electric oven (Fischer model Grill 16, Brazil), for 40 minutes, in the laboratory of the Nutrition College. A digital thermometer was used (Incoterm modelo ST9227B, Brazil) to measure the temperature. Afterwards, sausages were cooled at room temperature and cut into $20 \mathrm{~mm}$-length cylinders, and their shear force (SF) was determined with a probe (Warner-Bratzler), moving at a pre-test speed of $1.0 \mathrm{~mm} / \mathrm{s}$; test speed of $2.0 \mathrm{~mm} . \mathrm{s}^{-1}$; posttest speed $10.0 \mathrm{of} \mathrm{mm} \cdot \mathrm{s}^{-1}$; and sample distance of $65 \mathrm{~mm}$ (Bressan et al., 2011). Five measurements were taken per treatment. Results were expressed in Newton (N) for the maximum force necessary to cut the samples.

The water-holding capacity (WHC) was measured by employing the methodology described by Ramos and Gomide (2009). The methodology described by Koohmaraie, Wheeler and Shackelford (1998) was utilized to calculate the cooking weight loss (CWL).

\section{Microbiological analyses of the sausage}

The microbiological analyses were performed in the meat portion to determine the hygienic-sanitary conditions of the raw material and in samples of the three sausage formulations on days $0,3,7$, and 12 of cold storage at $4{ }^{\circ} \mathrm{C}$ to monitor the microbiological growth. The analyses comprised the count of total and thermo-tolerant coliforms, detection of Salmonella spp., counts of mesophilic aerobic heterotrophic and psychrotrophic aerobic heterotrophic bacteria, and detection and identification of coagulasepositive staphylococci. The American Public Health Association methodologies described in the 3rd edition of Compendium of Methods for the Microbiological Examination of Foods (Downes; Ito, 1992) were adopted.

\section{Sensory analyses of the sausage}

The sensory evaluation of the sausage samples was accomplished by an affective acceptance test using a structured five-point hedonic scale varying from "really liked it" (score 5) to "really disliked it" (score 1). The evaluated attributes were: aroma, color, flavor, juiciness, texture, and overall appearance (Faria; Yotsuyanagi, 2008).

The samples were previously baked in a gas oven that was kept heated until the moment of the sensory analyses and presented to the evaluators in disposable plastic cups identified with random three-digit figures. The purchase intention of the tasters was also evaluated, aiming to determine if they would buy the products. The participants consisted of 84 untrained volunteers of both genders among students, professors, and workers at UFMT. This study was approved by the Ethics Committee on Research with Human Beings of UFMT (protocol CAAE 36002614.0.0000.5541).

\section{Statistical analysis}

For the physicochemical analyses, the experiment was conducted in a Completely Randomized Design (CRD), in which the treatments consisted of three levels of fat with six replicates, totaling 18 observations. Analysis of variance (ANOVA) was performed and means were compared by the Scott-Knott test.

A completely randomized design was used for the microbiological analyses, in which the factors consisted of four shelf-life times and three levels of fat concentration. The ANOVA and the comparison of means were calculated. To check the ANOVA's assumptions, the Shapiro-Wilk test was performed for error normality, and the Barllet test for homogeneity of variance. After the difference between the times was detected, a regression analysis was carried out.

In the sensory analysis, a randomized block design was established, in which the treatments consisted of three levels of fat. Eighty-four (84) blocks (untrained tasters) were used per treatment, thus totaling 252 observations. The measured variables were: color, flavor, juiciness, texture, aroma and overall appearance. The statistical analysis was performed using a nonparametric ANOVA by the Friedman test.

Statistical analyses were carried out on the $\mathrm{R}$ Development Core Team (2013) statistical package.

\section{RESULTS AND DISCUSSION}

\section{Evaluation of raw-material quality}

The results of the microbiological analyses performed in the meat portion utilized in the preparation of the sausages showed its good hygienic-sanitary quality. The fecal coliforms and coagulase-positive Staphylococcus were $<1 \log \mathrm{CFU} \mathrm{g}^{-1}$, and detection of Salmonella spp. indicated absence in $25 \mathrm{~g}$; these values are in line with 
the limits tolerated by the current legislation (fecal coliforms $10^{2}$; coagulase positive Staphylococcus $5 \times 10^{2}$ and negative Salmonella spp) (Brasil, 2001). For the heterotrophic aerobic mesophilic and psychrotrophic bacteria, however, mean values were 3.3 and $1.5 \mathrm{log}$ $\mathrm{CFU} \mathrm{g}^{-1}$, respectively. These results indicate a good quality of the fish farmed in water tanks. There are no standards in Brazil for the count of mesophilic and psychrotrophic bacteria in fish; however, the International Commission on Microbiological Specifications for Foods (ICMSF, 1986) recommends that the population of these bacteria in food intended for human consumption not exceed 7.0 $\log$ CFU g ${ }^{-1}$. Studying the quality and formulation of fresh sausage of Indian sardines (Sardinella longiceps), Ravishankar, Setty and Shetty (1992) found similar results, with $3.99 \log$ CFU.g ${ }^{-1}$ mesophilic on day zero. In the same way, studying the microorganisms of fresh sausage of tilapia, (Oreochromis niloticus), Oliveira Filho et al (2010) observed psychrotrophs during storage, and the initial results were $\leq 2 \log \mathrm{CFU} \mathrm{g}^{-1}$. These results show that low contamination of fish post-capture is of fundamental importance to generate fish products of high quality.

The average BNVT for the evaluated samples of the meat portion was $13.02 \mathrm{mg} \mathrm{N} .100 \mathrm{~g}^{-1}$. Quantifying the BNVT is recommended in the procedures of fishquality inspection by several official agencies such as the Regulation of Industrial and Sanitary Inspection of Animal Products (AOAC, 2012). For the Brazilian legislation, the maximum tolerated limit for fish to be marketed is $30 \mathrm{mg}$ N.100 g ${ }^{-1}$ (Brasil, 1997).

Concerning the $\mathrm{pH}$, the raw material conformed to RIISPOA (Brasil, 1952), in which fish can be considered fresh when its $\mathrm{pH}$ varies from 6.8 to 6.5 . The average $\mathrm{pH}$ of each meat portion was 6.6 , demonstrating their quality.

Regarding the centesimal composition of the tambaqui meat portion, the average results were 77.65 g. 100 $\mathrm{g}^{-1}$ moisture, $18.81 \mathrm{~g} .100 \mathrm{~g}^{-1}$ protein, $2.16 \mathrm{~g} .100 \mathrm{~g}^{-1}$ fat, and 1.25 g. $100 \mathrm{~g}^{-1}$ ash, comprising a caloric value of 95.2 Kcal.100 $\mathrm{g}^{-1}$. The obtained results are in agreement with those found by Cartonilho and Jesus (2011), who studied the proximate composition of frozen cuts of farmed tambaqui.

\section{Physicochemical analyses of the sausage}

Based on the results shown in Table 2, the carbohydrate, protein, and ash values found in the three sausage formulations varied little between each other, and no significant statistical difference occurred $(p<0.05)$ between their means for the different treatments. However, a significant difference ( $p>0.05)$ was observed in the average lipid contents and caloric value as the added fat content was increased. Treatment F2 displayed the highest lipid content and consequently the highest caloric value.

A statistically significant difference was also observed between the average moisture values of the samples from the different treatments. The moisture values were inversely proportional to the lipid content. With an increase in the concentration of the fat added to the formulations, the amount of meat was reduced, which would possibly explain the reduced moisture content, because the average moisture result of the meat portion used in the formulations was $77.65 \mathrm{~g} .100 \mathrm{~g}^{-1}$.

There is no specific legislation for fish sausages in Brazil, but the legislation for fresh sausages (raw, desiccated sausages) requires a maximum amount of $70 \%$ moisture and $30 \%$ fat, and a minimum of $12 \%$ protein (Brasil, 2000). The results found in this study show that the moisture contents of treatments $\mathrm{C}$ and $\mathrm{F} 1$ were higher than that established by the legislation, and treatment F2 met the legislation's recommendations.

The centesimal composition values found in this study are similar to those obtained in other studies with fishbased sausages; however, Chuapoehuk, Raksakulthai and Worawattanamateekul (2001) found a variation in protein content from 13.67 to $13.91 \mathrm{~g} .100 \mathrm{~g}^{-1}$, and Bispo et al. (2004) found that the lipid concentration was $16.54 \mathrm{~g} .100 \mathrm{~g} \mathrm{~g}^{-1}$. The protein values were lower than those in the present study, perhaps because the proportion of fish meat:surimi was 40\%:60\%, resulting in less protein because surimi has a lower protein content. According to the literature, the content and composition of the protein of fish may vary depending on the species, size, sex, time of the year, and other factors (Ogawa, 1999). The lower lipid content of hybrid Clarias catfish was probably the explanation for the obtained results.

Table 2: Centesimal composition (g.100 $\mathrm{g}^{-1}$ ) of the different sausage formulations.

\begin{tabular}{ccccccc}
\hline Formulation & Moisture* & Proteins* & Lipids* & Ash* & Carbohydrates* & Caloric value** \\
\cline { 2 - 6 } C & $72.73 \mathrm{a}$ & $18.88 \mathrm{a}$ & $2.90 \mathrm{a}$ & $4.20 \mathrm{a}$ & $1.277 \mathrm{a}$ & $106.697 \mathrm{a}$ \\
F1 & $71.05 \mathrm{~b}$ & $18.90 \mathrm{a}$ & $5.45 \mathrm{~b}$ & $4.04 \mathrm{a}$ & $1.300 \mathrm{a}$ & $130.492 \mathrm{~b}$ \\
F2 & $68.82 \mathrm{c}$ & $18.85 \mathrm{a}$ & $8.33 \mathrm{c}$ & $3.86 \mathrm{a}$ & $1.277 \mathrm{a}$ & $155.475 \mathrm{c}$ \\
\hline
\end{tabular}

Means followed by equal letters in the same column do not differ at $5 \%$ significance. $\mathrm{N}=$ Newton. $\mathrm{C}=0 \%$ fat addition; $\mathrm{F} 1=4.5 \%$ fat addition; $\mathrm{F} 2=9 \%$ fat addition; $*$ g. $100 \mathrm{~g}^{-1} ; * * \mathrm{~K} \cdot \mathrm{cal}^{-1}$. 
Studies demonstrate that texture is related to the centesimal composition of meat products, varying according to their water (Cofrades et al., 2000), protein, and fat (Cengiz; Gokoglu, 2007) contents. According to Colmenero et al. (1995) and Lee Whiting and Jenkins (1987), higher fat contents imply a reduction in the texture attributes, which occurs mainly when the increase in fat is followed by a decrease in the protein and water contents in the formulations. In the present experiment, it was proved that as the fat content of the treatments is increased, texture is reduced probably due to the reduction of the moisture content. Shear force was significantly lower $(p<0.05)$ in treatment F2 (Table 3). In their study, Huda et al. (2012) compared five commercial samples of fish sausage and found $\mathrm{SF}$ values ranging from 5.29 to $10.98 \mathrm{~N}$; these values are within the range of values observed in this work.

Table 3: Physical analyses of the different sausage formulations.

\begin{tabular}{cccc}
\hline & \multicolumn{3}{c}{ Mean } \\
\cline { 2 - 4 } Formulation & SF (N) & WHC (\%) & CWL (\%) \\
\cline { 2 - 4 } C & $8.14 \mathrm{a}$ & $74.61 \mathrm{a}$ & $24.21 \mathrm{a}$ \\
F1 & $7.67 \mathrm{a}$ & $71.83 \mathrm{a}$ & $26.59 \mathrm{a}$ \\
F2 & $5.92 \mathrm{~b}$ & $74.71 \mathrm{a}$ & $25.57 \mathrm{a}$ \\
\hline
\end{tabular}

Means followed by equal letters in the same column do not differ at $5 \%$ significance. $\mathrm{N}=$ Newton, $\mathrm{C}=0 \%$ fat addition, $\mathrm{F} 1=4.5 \%$ fat addition, $\mathrm{F} 2=9 \%$ fat addition, $\mathrm{SF}=$ shear force, $\mathrm{WHC}=$ water-holding capacity, CWL $=$ cooking weight loss.

As occurred with WHC, cooking weight losses did not differ statistically among the treatments $(p>0.05)$ (Table 3). The cooking weight loss is defined as the meat's ability to retain water, even when external pressures are applied onto it, such as cutting, heating, grinding, and pressing. Excessive losses result in economic losses in many ways, both to consumers and to the industry. Besides water, protein and vitamins are components carried away with the loss of moisture, which may affect the processing characteristics. The meat WHC is inversely related to CWL (Huff-Lonergan; Lonergan, 2005): the higher the WHC, the lower the CWL, as demonstrated in the present study.

\section{Microbiological analyses}

The results of the microbiological analyses are shown in Table 4. No pathogenic microorganisms were detected in the treatments during the 12 days of storage at $4{ }^{\circ} \mathrm{C}$.
Table 4: Microbiological analyses of the different sausage formulations.

\begin{tabular}{clllc}
\hline \multicolumn{5}{c}{ Mesophiles* } \\
\hline Formulation & Day 0 & Day 3 & Day 7 & Day 12 \\
\cline { 2 - 5 } C & $4.51 \mathrm{a}$ & $2.77 \mathrm{a}$ & $4.38 \mathrm{a}$ & $5.58 \mathrm{a}$ \\
$\mathrm{F} 1$ & $3.27 \mathrm{a}$ & $3.74 \mathrm{~b}$ & $5.00 \mathrm{a}$ & $6.61 \mathrm{a}$ \\
$\mathrm{F} 2$ & $3.34 \mathrm{a}$ & $4.31 \mathrm{~b}$ & $5.07 \mathrm{a}$ & $6.81 \mathrm{a}$ \\
\hline \multicolumn{5}{c}{ Psychrotrophs* } \\
\hline Formulation & Day 0 & Day 3 & Day 7 & Day 12 \\
\cline { 2 - 5 } $\mathrm{C}$ & $2.33 \mathrm{a}$ & $3.76 \mathrm{a}$ & $4.2 \mathrm{a}$ & $6.1 \mathrm{a}$ \\
$\mathrm{F} 1$ & $1.35 \mathrm{a}$ & $3.65 \mathrm{a}$ & $5.3 \mathrm{a}$ & $7.3 \mathrm{a}$ \\
$\mathrm{F} 2$ & $1.82 \mathrm{a}$ & $7.7 \mathrm{a}$ & $5.66 \mathrm{a}$ & $7.3 \mathrm{a}$ \\
\hline \multicolumn{5}{c}{ Total coliforms* } \\
\hline Formulation & Day 0 & Day 3 & Day 7 & Day 12 \\
\cline { 2 - 5 } $\mathrm{C}$ & $2.32 \mathrm{a}$ & $2.28 \mathrm{a}$ & $2.93 \mathrm{a}$ & $3.5 \mathrm{a}$ \\
F1 & $3.35 \mathrm{a}$ & $2.37 \mathrm{a}$ & $2.94 \mathrm{a}$ & $4.39 \mathrm{a}$ \\
F2 & $2.5 \mathrm{a}$ & $2.2 \mathrm{a}$ & $3.69 \mathrm{a}$ & $4.1 \mathrm{a}$ \\
\hline \multicolumn{5}{c}{ Thermo-tolerant coliforms* } \\
\hline Formulation & Day 0 & Day 3 & Day 7 & Day 12 \\
\cline { 2 - 5 } $\mathrm{C}$ & $1.3 \mathrm{a}$ & $1.4 \mathrm{a}$ & $1.6 \mathrm{a}$ & $1.8 \mathrm{a}$ \\
F1 & $1.4 \mathrm{a}$ & $1.26 \mathrm{a}$ & $1.36 \mathrm{a}$ & $2.26 \mathrm{a}$ \\
F2 & $1.2 \mathrm{a}$ & $1.3 \mathrm{a}$ & $1.5 \mathrm{a}$ & $2.2 \mathrm{a}$ \\
\hline
\end{tabular}

Means followed by equal letters in the same column do not differ at $5 \%$ significance. $\mathrm{C}=0 \%$ fat addition, $\mathrm{F} 1=4.5 \%$ fat addition, $\mathrm{F} 2=9 \%$ fat addition. ${ }^{*} \log \mathrm{CFU} \mathrm{g}{ }^{-1}$.

For total and thermo-tolerant coliforms, no statistical difference $(\mathrm{p}>0.05)$ was found among the different treatments (Table 4).

The count of psychrotrophic bacteria present in the sausages showed an increasing multiplication from day zero to the twelfth day of cold storage without significant differences among the treatments $(\mathrm{p}>0.05)$ (Table 4). In a sausage prepared with Nemipterus japonicas (Raju; Shamasundar; Udupa, 2003), an increase in the count of psychrotrophic bacteria was only observed from 30 days of storage at $6^{\circ} \mathrm{C}$.

The mesophilic bacteria showed an increased growth from day zero; however, when the sausage was subjected to refrigeration, this count decreased due to the action of the temperature on this bacterial class, which notably grows at room temperature (Table 4). According to the results presented only on day 3 , it was found that the sausages with fat (F1 and F2) showed a significantly 
higher count of mesophilic bacteria than the sausage with no fat $(C)(p<0.05)$, with no significant differences for the other times $(\mathrm{p}>0.05)$.

The Brazilian legislation (Brasil, 2001) has no specific norms established for fish sausages, although for products based on cooled or frozen fish the limits for bacterial contamination are: thermo-tolerant coliforms, maximum of $10^{3} \mathrm{CFU} . \mathrm{g}^{-1}$; maximum coagulase-positive Staphylococcus of $10^{3} \mathrm{CFU} \cdot \mathrm{g}^{-1}$; and Salmonella, absence in $25 \mathrm{~g}$ of sample. There are no limits for the counts of total coliforms or mesophilic and psychrotrophic aerobic bacteria.

Nevertheless, the ICMSF (1986) recommends that the population of these bacteria in foods intended for human consumption not exceed $7.0 \mathrm{log}$ CFU. ${ }^{-1}$. Stannard (1997) established a minimum and a maximum limit for the count of mesophilic and psychrotrophic bacteria of 5 to $7 \log \mathrm{CFU} \cdot \mathrm{g}^{-1}$, respectively, and results above the minimum value indicate deterioration and non-acceptance of the meat products. Therefore, all treatments remained within the limits established by the literature until the seventh day of cold storage, so they were suitable for consumption.

Oliveira Filho et al. (2010) did not detect pathogenic microorganisms (Staphylococcus aureus and Salmonella sp.) in a sausage based on minced Nile tilapia (O. niloticus) and total coliform population in the sausage evaluated by the Most Probable Number (MPN) method. In addition, according to those authors, the population of psychrotrophic bacteria showed a rather pronounced multiplication after 40 days of storage at $0{ }^{\circ} \mathrm{C}$.

\section{Sensory Analysis}

The sensory analysis demonstrated that the treatments were well accepted by the tasters. Considering the average acceptability index of the attributes for each treatment (Table 5), it can be observed that all of them showed acceptability values above $80 \%$. According to Dutcosky (2011), the acceptability index of $70 \%$ is the minimum percentage for a product to be considered accepted in terms of sensory traits. However, it should be emphasized that although they were not evaluated statistically, higher mean values for acceptability were obtained by treatment F2, which was produced with a higher fat content, followed by F1, with an intermediate level of fat, and lastly treatment $\mathrm{C}$, which had no fat addition, suggesting greater preference, by the judges, for the sausage with the highest fat contents. According to Juárez et al. (2012), the fat has an important role in the acceptability of a meat; in addition to being associated with flavor, tenderness and juiciness, fat provides the lubrication between the muscle fibers, increasing the perception of tenderness and juiciness in the meat. Veit et al. (2012) and Neiva et al. (2011) also found high acceptability rates in products developed from fish.

The purchase intention of the participants was also questioned in the sensory analysis. Regarding treatment $\mathrm{C}, 34.5 \%$ said they would definitely buy it. For treatment F1, the resolute intention to buy was $37 \%$. Treatment F2, in turn, obtained the highest percentage of tasters decided to acquire the product, accumulating $61 \%$ of the purchase intentions. In this regard, an increasing purchasing intention was found as the concentration of fat in the treatments was increased.

According to Table 6, the means of the scores given by the tasters for the aroma, color, texture, and overall appearance attributes did not show a significant statistical difference at the significance levels of $\mathrm{p}=0.08112, \mathrm{p}=0.6712, \mathrm{p}=0.08438$, and $\mathrm{p}=0.1712$, respectively. For the attribute flavor, the treatment with most fat addition (F2) showed a significantly higher score $(p=0.01009)$ than the others. Sausages with fat (F1 and F2) showed a significantly higher $(\mathrm{p}=0.01469)$ average score for the juiciness attribute than the control group, which had no fat addition.

Table 5: Indices of acceptability of the sensory attributes for the different formulations.

\begin{tabular}{ccccccc}
\hline & \multicolumn{7}{c}{ Index of acceptability } \\
\hline Formulation & Aroma & Color & Flavor & Juiciness & Texture & Overall appearance \\
\cline { 2 - 7 } C & 82.8 & 80.2 & 85.4 & 83.2 & 82.6 & 83.2 \\
F1 & 85.6 & 81 & 86.6 & 87 & 85.2 & 82.2 \\
F2 & 86.6 & 83.4 & 92 & 88.2 & 87.2 & 85.8 \\
\hline
\end{tabular}

$\mathrm{C}=0 \%$ fat addition, $\mathrm{F} 1=4.5 \%$ fat addition, $\mathrm{F} 2=9 \%$ fat addition. 
Table 6: Test of comparison of means for the attributes of the different formulations.

\begin{tabular}{ccccccc}
\hline & \multicolumn{7}{c}{ Attribute } \\
\cline { 2 - 7 } Formulation & Aroma & Color & Flavor & Juiciness & Texture & Overall appearance \\
\cline { 2 - 7 } C & $4.143 \mathrm{a}$ & $4.012 \mathrm{a}$ & $4.274 \mathrm{a}$ & $4.167 \mathrm{a}$ & $4.131 \mathrm{a}$ & $4.167 \mathrm{a}$ \\
F1 & $4.286 \mathrm{a}$ & $4.059 \mathrm{a}$ & $4.333 \mathrm{a}$ & $4.357 \mathrm{~b}$ & $4.262 \mathrm{a}$ & $4.119 \mathrm{a}$ \\
F2 & $4.333 \mathrm{a}$ & $4.178 \mathrm{a}$ & $4.607 \mathrm{~b}$ & $4.417 \mathrm{~b}$ & $4.369 \mathrm{a}$ & $4.298 \mathrm{a}$ \\
\hline
\end{tabular}

Means followed by equal letters in the same column do not differ at $5 \%$ significance. $\mathrm{C}=0 \%$ fat addition, $\mathrm{F} 1=4.5 \%$ fat addition, $\mathrm{F} 2=9 \%$ fat addition.

\section{CONCLUSIONS}

All the evaluated treatments showed an elevated nutritional state, with an important emphasis for the protein contents. Moreover, they showed satisfactory microbiological conditions until the seventh day of cooled storage. There was also high sensory acceptability for all treatments regarding the evaluated attributes, with greater preference for the treatment with the largest amount of fat. The high acceptance rate and intention to purchase these products reinforce the market potential of this sausage, with the prospect of the insertion of a new product in the market.

\section{REFERENCES}

Association of Official Analytical Chemists-AOAC. Offi $\mathrm{c}$ i a I Methods of Analysis of the Association of Official Analytical Chemists (19th Ed.). Washington: AOAC International, 2012.

BISPO, E.S. et al. Aproveitamento industrial de marisco na produção de linguiça. Ciência e Tecnologia de Alimentos. 24(4):664-668, 2004.

BRASIL. Ministério da Agricultura, Pecuária e Abastecimento. RIISPOA - Regulamento da Inspeção Industrial e Sanitária de Produtos de Origem Animal. Decreto no 30691, of 03/29/52. Brasília/DF: Ministério da Agricultura, Pecuária e Abastecimento, 1952.

BRASIL. Ministério da Agricultura, Pecuária e Abastecimento. Portaria $\mathrm{n}^{\circ} 1$ de 07 de outubro de 1981. Aprova os Métodos Analíticos para Controle de Produtos de Origem Animal e seus Ingredientes: Métodos Físicos e Químicos. Diário Oficial da União DF of October 13, 1981.

BRASIL. Ministério da Agricultura, Pecuária e Abastecimento - MAPA. 1997. Regulamento técnico de identidade e qualidade de peixe fresco (inteiro e eviscerado). Portaria $\mathrm{N}^{\circ} 185$ of 05/13/1997. Brasília.

BRASIL. Ministério da Agricultura, Pecuária e Abastecimento - MAPA. Instrução Normativa $n^{\circ} 4$. Anexo III - Regulamento Técnico de Identidade e Qualidade de linguiça. Diário Oficial da União, Brasília, April 05, 2000.

BRASIL. Ministério da Saúde. Agência Nacional de Vigilância Sanitária - ANVISA. Regulamento Técnico sobre padrões microbiológicos para alimentos. Resolução RDC $n^{\circ} 12$, de 02 de janeiro de 2001. Diário Oficial da União, of January 10, 2001. Brasília, 2001. $47 \mathrm{p}$.

BRASIL. Ministério da Saúde. Agência Nacional de Vigilância Sanitária. Resolução RDC no 360/2003. Aprova Regulamento Técnico sobre Rotulagem Nutricional de Alimentos Embalados, tornando obrigatória a rotulagem nutricional. D.O.U. Diário Oficial da União; Poder Executivo, Dec. 26, 2003.

BRASIL. Ministério da Agricultura, Pecuária e Abastecimento - MAPA. Instrução Normativa $n^{\circ} 25$. Métodos analíticos oficiais físico-químicos para controle de pescado e seus derivados. Diário Oficial da União, Brasília, 2 de junho de 2011.

BRESSAN, M. C. et al. Physicochemical properties of meat from Bos taurus and Bos indicus. Revista Brasileira de Zootecnia. 40(6):1250-1259, 2011.

BRUNNER, T. A.; HORST, K.; SIEGRIST, M. Convenience food products. Drivers for consumption. Appetite. 55:498-506, 2010. 
BURGER, J. Fishing, fish consumption, and awareness about warnings in a university community in central New Jersey in 2007, and comparisons with 2004.

Environmental Research. 108:107-116, 2008.

CARTONILHO, M. M.; JESUS, R. S. Qualidade de cortes congelados de tambaqui cultivado. Pesquisa Agropecuária Brasileira. 46(4), 2011.

CENGIZ, E.; GOKOGLU, N. Effects of fat reduction and fat replacer addition on some quality characteristics of Frankfurter-type sausages. International Journal of Food Science and Technology. 42:366-372, 2007.

CHUAPOEHUK, P.; RAKSAKULTHAI, N.; WORAWATTANAMATEEKUL, W. Process development of fish sausage. International Journal Of Food Properties. 4(3):523-529, 2001.

COFRADES, S. et al. Plasma protein and soy fiber content effect on bologna sausage properties as influenced by fat level. Journal of Food Science. 65(2), 2000 .

COLMENERO, F. J. et al. Influence of protein and fat content and cooking temperature on texture and sensory evaluation of bologna sausage. LebensmittelWissenschaft und-Technologie. 28(5):48-487, 1995.

DOWNES, F. P.; ITO, K. Compendium of Methods for the Microbiological Examination of Foods. $3^{\circ}$ ed. Washington: American Public Health Association (APHA), 1992. 1219p.

DUTCOSKY, S. D. Análise sensorial de alimentos. $3^{\mathrm{a}}$ ed. Curitiba: Editora Universitária Champagnat, 2011. 426p.

FARIA, E. V.; YOUTSUYANAGI, K. Técnicas de Análise Sensorial. 2ed. Instituto de Tecnologia de Alimentos - ITAL. Campinas: 2008. 120p.

GONCCALVES, A. A. O processo de desenvolvimento de produtos. In: GONÇALVES, A. A. Tecnologia do pescado: ciência, tecnologia, inovação e legislação. São Paulo. Editora Atheneu. 2011, p.274-290.

HUDA, N. et al. Some quality characteristics of malaysian comercial fish sausage. Pakistan Jornal of Nutrition. 11(8):798-803, 2012.
HUFF-LONERGAN, E.; LONERGAN, S. M. Mechanisms of water-holding capacity of meat: The role of postmortem biochemical and structural changes. Meat Science. 71:194-204, 2005.

ICMSF. International Commission of Microbiological Specifications for Foods.

Microorganisms in food sampling for microbiological analysis: Principles and specific applications. London: Blackwell Scientific Publications, 1986. 448p.

JUÁREZ, M. et al. Beef texture and juiciness. In: Hui Y. H, editor. Handbook of Meat and Meat Processing. 2nd ed. CRC; 2012. p.177-188.

KOOHMARAIE, M.; WHEELER, T. L.; SHACKELFORD, S.D. Beef tenderness: regulation and prediction. Center, NE: USDA-ARS, US Meat Animal Research Center, 1998. 90p.

LARA, J. A. F.; GARBELINI, J. S.; DELBEM, A. C. B. Tecnologias para a agroindústria: processamento artesanal do pescado do pantanal. Corumbá: Embrapa Pantanal, 2007. 5p. (Embrapa Pantanal. Circular Técnica, 73).

LEE, C. M.; WHITING, R. C.; JENKINS, R. K. Texture and sensory evaluations of frankfurters made with different formulations and processes. Journal of Food Science. 52:896-900, 1987.

LEEK, S.; MADDOCK, S.; FOXALL, G. Situational determinants of fish consumption. British Food Journal. 102:18-39, 2000.

NEIVA, C. R. P. et al. Fish crackers development from minced fish and starch: an innovative approach to a traditional product. Ciência e Tecnologia dos Alimentos. 31(4):973-979, 2011.

OLIVEIRA FILHO, P. R. C. Quality of sausage elaborated using minced Nile Tilapia submmitted to cold storage. Scientia Agricola. 67(2):183-190, 2010 .

OGAWA, M.; MAIA, E. Manual de pesca: ciência e tecnologia do pescado. São Paulo: Varela, 1999. v.1, 430p. 
PREGNOLATTO, W.; PREGNOLATTO, N. P. Normas analíticas do Instituto Adolfo Lutz: métodos químicos e físicos para análise de alimentos. 3. ed. São Paulo: Instituto Adolfo Lutz, 1985. 533p.

RAJU, C. V.; SHAMASUNDAR, B. A.; UDUPA, K. $\mathrm{S}$. The use of nisin as a preservative in fish sausage stored at ambient $\left(28 \pm 2{ }^{\circ} \mathrm{C}\right)$ and refrigerated $\left(6 \pm 2{ }^{\circ} \mathrm{C}\right)$ temperatures. International Journal of Food Science and Technology. 38:171-185, 2003.

RAMOS, E. M.; GOMIDE, L. A. M. Avaliação da qualidade de carnes: fundamentos e metodologias. Viçosa/MG. Editora da Universidade Federal de Viçosa, 2009, 599p.

RAVISHANKAR, C. N.; SETTY, T. M. R.; SHETTY, T. S. Method for the preparation of sausages of acceptable quality from Indian oil sardine (Sardinella longiceps) and their shelf-life at different storage temperatures. Food Control. 3(3):144-148, 1992.

SCHOLDERER, J.; TRONDSEN, T. The dynamics of consumer behavior? On habit, discontent and other fish to fry. Appetite. 51:576-591, 2008.

STANNARD. C. Development and use of microbiological criteria for foods. Food Science and Technology Today. London, 11(3), 137-176, 1997.

VEIT, J. C. et al. Desenvolvimento e caracterização de bolos de chocolate e de cenoura com filé de tilápia do nilo (Oreochromis niloticus). Alimentos e Nutrição. 23(3):427-433, 2012. 